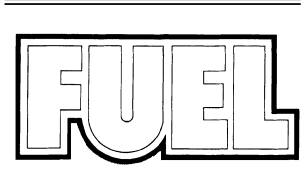

Fuel 79 (2000) 607-616

www.elsevier.com/locate/fuel

\title{
Measurements and modelling of wax formation in diesel fuels
}

\author{
J.A.P. Coutinho ${ }^{\mathrm{a}, *}$, C. Dauphin ${ }^{\mathrm{b}}$, J.L. Daridon ${ }^{\mathrm{b}}$ \\ ${ }^{a}$ Centro de Investigação em Química, FCUP, Departamento de Química da Universidade de Aveiro, 3810 Aveiro, Portugal \\ ${ }^{\mathrm{b}}$ Laboratoire Haute Pression, Université de Pau et des Pays de l'Adour, 64000 Pau, France
}

Received 11 May 1999; received in revised form 20 July 1999; accepted 25 July 1999

\begin{abstract}
Wax formation in hydrocarbon fluids at low temperatures is one of the harassing problems faced by the petroleum industry. The prevention of wax formation, the production of diesels more resistant at low temperatures and the design of new and better additives requires a good understanding of the crystallisation behaviour of the paraffin molecules. Better experimental techniques to study the wax formation and reliable thermodynamical models, able to predict the solid-liquid equilibrium of petroleum fluids, would help to prevent and overcome many of the problems associated with wax deposition.

Here, an equilibrium cell previously used with synthetic mixtures is applied to study the influence of the desulphuration on the low temperature behaviour of a Petrogal diesel. The compositions of the solid and liquid phases in equilibrium and the fraction of solids in partly crystallised solutions were measured between -5 and $-20^{\circ} \mathrm{C}$. The latter was also measured by DSC. The experimental data was modelled using the Predictive UNIQUAC model. It is shown that the model provides an excellent description of the measured phase behaviour for these diesels. The desulphuration of the diesel seems to make it slightly heavier and to increase its wax appearance temperature (WAT). (c) 2000 Elsevier Science Ltd. All rights reserved.
\end{abstract}

Keywords: Diesel fuels; Wax formation; Solid-liquid equilibrium model

\section{Introduction}

The Auto-Oil program from the European Commission aims at reducing the emissions of the car fuels [1]. It has already lead to low sulphur content diesels, unleaded gasolines and should, in the near future, severely reduce the aromatics present in fuels. The trend, in what concerns hydrocarbons, is clearly towards less aromatic and more paraffinic fuels $[2,3]$. The advantages from the environment and combustion point of view have, however, some drawbacks such as a poorer behaviour at low temperatures.

For a typical diesel, without additives, at temperatures below $10^{\circ} \mathrm{C}$ the paraffins start to crystallise forming plates and needles that plug pipes and filters. A few degrees below the wax appearance point (WAP) the solution gels completely preventing the flow of the fuel. To produce fuels that conform to the new European standards and at the same time are robust for use at low temperatures it is important to be able to relate the wax formation with the composition of the fluid. This will help to adequately design the production and blend of fuels, as well as to select the most adequate additives [4].

\footnotetext{
* Corresponding author.

E-mail address: jcoutinho@dq.ua.pt (J.A.P. Coutinho).
}

This work analyses the effect of the desulphuration process used at the Petrogal refinery in the low temperature behaviour of a diesel. This is done by extending to real fluids, apparatuses and theoretical models that had proven valuable in the study of synthetic paraffinic mixtures [5-8]. Extensive measurements of composition and phase equilibria are done to the diesel before and after desulphuration and the results compared. A description of the experimental data is done with the Predictive UNIQUAC model. It is shown that an excellent agreement with the experimental data is obtained.

\section{Experimental}

Basic compositional information concerning the PNA distribution and the average molecular weight for the two diesels studied was known from standard refinery analysis. The paraffinic fraction was confirmed by GC and a detailed analysis is presented in Table 1 for the two diesels. They are hereafter labelled S (pre-desulphuration diesel) and NS (desulphured diesel).

\subsection{Gas chromatography}

To measure the composition of the diesels, and the 
Table 1

Composition, PNA distribution and average $M_{\mathrm{w}}$ of the diesels

\begin{tabular}{|c|c|c|}
\hline & Diesel S (mass fractions) & Diesel NS (mass fractions) \\
\hline$n-\mathrm{C} 10$ & $1.544 \mathrm{E}-03$ & $1.392 \mathrm{E}-03$ \\
\hline$n-\mathrm{C} 11$ & $1.727 \mathrm{E}-03$ & $1.957 \mathrm{E}-03$ \\
\hline$n-\mathrm{C} 12$ & $4.656 \mathrm{E}-03$ & $4.235 E-03$ \\
\hline$n-\mathrm{C} 13$ & $8.048 \mathrm{E}-03$ & $9.121 \mathrm{E}-03$ \\
\hline$n-\mathrm{C} 14$ & $1.018 \mathrm{E}-02$ & $1.047 \mathrm{E}-02$ \\
\hline$n-\mathrm{C} 15$ & $1.213 \mathrm{E}-02$ & $1.278 \mathrm{E}-02$ \\
\hline$n-\mathrm{C} 16$ & $9.850 \mathrm{E}-03$ & $1.010 \mathrm{E}-02$ \\
\hline n-C17 & $9.642 \mathrm{E}-03$ & $9.694 \mathrm{E}-03$ \\
\hline$n-\mathrm{C} 18$ & $7.987 \mathrm{E}-03$ & $8.111 \mathrm{E}-03$ \\
\hline$n-\mathrm{C} 19$ & $7.008 \mathrm{E}-03$ & $7.138 \mathrm{E}-03$ \\
\hline$n-\mathrm{C} 20$ & $6.228 \mathrm{E}-03$ & $6.617 \mathrm{E}-03$ \\
\hline$n-\mathrm{C} 21$ & $5.547 \mathrm{E}-03$ & $5.612 \mathrm{E}-03$ \\
\hline$n-\mathrm{C} 22$ & $4.473 \mathrm{E}-03$ & $4.580 \mathrm{E}-03$ \\
\hline$n-\mathrm{C} 23$ & $3.763 \mathrm{E}-03$ & $3.814 \mathrm{E}-03$ \\
\hline$n-\mathrm{C} 24$ & $3.018 \mathrm{E}-03$ & $3.044 \mathrm{E}-03$ \\
\hline$n-\mathrm{C} 25$ & $2.587 \mathrm{E}-03$ & $2.631 \mathrm{E}-03$ \\
\hline$n-\mathrm{C} 26$ & $1.852 \mathrm{E}-03$ & $1.862 \mathrm{E}-03$ \\
\hline$n-\mathrm{C} 27$ & $1.293 \mathrm{E}-03$ & $1.314 \mathrm{E}-03$ \\
\hline$n-\mathrm{C} 28$ & $8.478 \mathrm{E}-04$ & $8.502 \mathrm{E}-04$ \\
\hline$n-\mathrm{C} 29$ & $6.122 \mathrm{E}-04$ & $6.342 \mathrm{E}-04$ \\
\hline$n-\mathrm{C} 30$ & $2.692 \mathrm{E}-04$ & $3.082 \mathrm{E}-04$ \\
\hline$n-\mathrm{C} 31$ & $1.998 \mathrm{E}-04$ & $1.921 \mathrm{E}-04$ \\
\hline$n-\mathrm{C} 32$ & $1.055 \mathrm{E}-04$ & $1.079 \mathrm{E}-04$ \\
\hline Paraffins & $1.036 \mathrm{E}-01$ & $1.066 \mathrm{E}-01$ \\
\hline Naphthenic & $6.564 \mathrm{E}-01$ & $6.717 \mathrm{E}-01$ \\
\hline Aromatic & $2.400 \mathrm{E}-01$ & $2.217 \mathrm{E}-01$ \\
\hline$M_{\mathrm{w}}(\mathrm{g} / \mathrm{mol})$ & 211.6 & 212.6 \\
\hline
\end{tabular}

samples coming from the equilibrium unit, a Hewlett Packard 6890 equipped with a hydrogen flame ionisation detector was used. The column used is composed by a precolumn of $1 \mathrm{~m}$ (i.d., $530 \mu \mathrm{m}$ ); two $30 \mathrm{~m}$ columns: the first an HP 5 MS (i.d. $320 \mu \mathrm{m}$ and film thickness $0.5 \mu \mathrm{m}$ ) and the second a HP 5 (i.d. $320 \mu \mathrm{m}$ and film thickness $0.25 \mu \mathrm{m}$ ); and a final empty column of about $30 \mathrm{~cm}$. The injection is performed on-column. On this chromatograph both the temperature and the carrier gas flow rate are programmable. To obtain a better separation of the heavy paraffins the gas flow rate is kept at $2 \mathrm{ml} / \mathrm{min}$ during the first $100 \mathrm{~min}$ and then increased to $3 \mathrm{ml} / \mathrm{min}$. The heating starts at $60^{\circ} \mathrm{C}$, is heated at $2.5^{\circ} \mathrm{C} / \mathrm{min}$ to $305^{\circ} \mathrm{C}$, and then at $2^{\circ} \mathrm{C} / \mathrm{min}$ up to $320^{\circ} \mathrm{C}$. Under these conditions paraffins between decane $(n-$ $\mathrm{C} 10)$ and dotriacontane $(n-\mathrm{C} 32)$ can be quantified. Nonane ( $n$-C9) [Aldrich, $>99 \%$ ] was used as reference and $\mathrm{CS}_{2}$ as solvent. A chromatogram for diesel NS is shown in Fig. 1.

\subsection{Equilibrium cell}

A diagram of the equilibrium cell used is presented in Fig. 2. It has been described in detail elsewhere [7,8]. Basically it is a thermostatic cell where the fluid is allowed to equilibrate for $18 \mathrm{~h}$ before sampling. The liquid phase is obtained by filtration of the sample pressing the filter cake. After melting, the residual fraction, composed of solids and entrapped liquid is also collected. GC analysis are made on both samples and the composition of the solid phase and fraction of solid material is obtained from material balances as described in Appendix A.

\subsection{Differential scanning calorimetry}

The calorimetric measurements were performed in a Setaram DSC 141. The sample was cooled to $-140^{\circ} \mathrm{C}$, kept at that temperature for $15 \mathrm{~min}$ to stabilise, and then heated up to $50^{\circ} \mathrm{C}$ at $3^{\circ} \mathrm{C} / \mathrm{min}$. A typical run is shown in Fig. 3 for diesel NS. They are similar to other DSC measurements for fuel and crudes previously reported in the literature $[9,10]$. After a glass transition at around $-80^{\circ} \mathrm{C}$, follows an exothermic peak due to the crystallisation of species that did not crystallise on cooling. Then a broad endothermic effect resulting from the dissolution of the paraffinic crystals in the liquid matrix appears. The major problem in the DSC analysis of these fluids is the definition of a base line. The approach of Claudy and Létoffé $[9,10]$ was followed here. A second-order polynomial is fitted to the liquid region and the basis of the exothermic peak where the dissolution of the paraffins begin. This is but an approximation, albeit the best available at the moment, and some incertitude is introduced in the calculations by its adoption. Using this base line the fraction of solids dissolved is obtained using an approach that proved adequate for complex synthetic mixtures and is described elsewhere [11].

\section{Wax formation modelling}

The wax formation is treated as a solid-liquid equilibrium of paraffins between a solution and an orthorhombic solid phase $[5,6]$. The general solid-liquid equilibrium equation relating the composition in both phases with the non-ideality of the phases and the pure component thermophysical properties is used [12]

$$
\begin{aligned}
\left(\ln \frac{s \gamma^{\mathrm{s}}}{x \gamma^{1}}=\right. & \frac{\Delta h_{\mathrm{m}}}{\mathrm{R} T_{\mathrm{m}}}\left(\frac{T_{\mathrm{m}}}{T}-1\right)+\frac{\Delta h_{\mathrm{tr}}}{\mathrm{R} T_{\mathrm{tr}}}\left(\frac{T_{\mathrm{tr}}}{T}-1\right) \\
& \left.-\frac{\Delta_{\mathrm{s}}^{1} C p_{\mathrm{m}}}{\mathrm{R}}\left(\ln \frac{T}{T_{\mathrm{m}}}+\frac{T_{\mathrm{m}}}{T}-1\right)\right)_{i} .
\end{aligned}
$$

Correlation for the heats and temperature of phase transition, based on the data presented by Broadhurst [13], used throughout this work are presented in Appendix A.

\subsection{The liquid phase non-ideality}

In liquid hydrocarbon mixtures, the non-ideality arises both from entropic effects such as size difference and free volume effects, and energetic interactions between unlike molecules as aromatics and aliphatics. The activity coefficient model used for the liquid phase is thus:

$\ln \gamma=\ln \gamma^{\mathrm{res}}+\ln \gamma^{\mathrm{comb}-\mathrm{fv}}$

where $\ln \gamma^{\text {res }}$ is given by modified UNIFAC [14,15] and describes the energetic interactions between the molecules. 


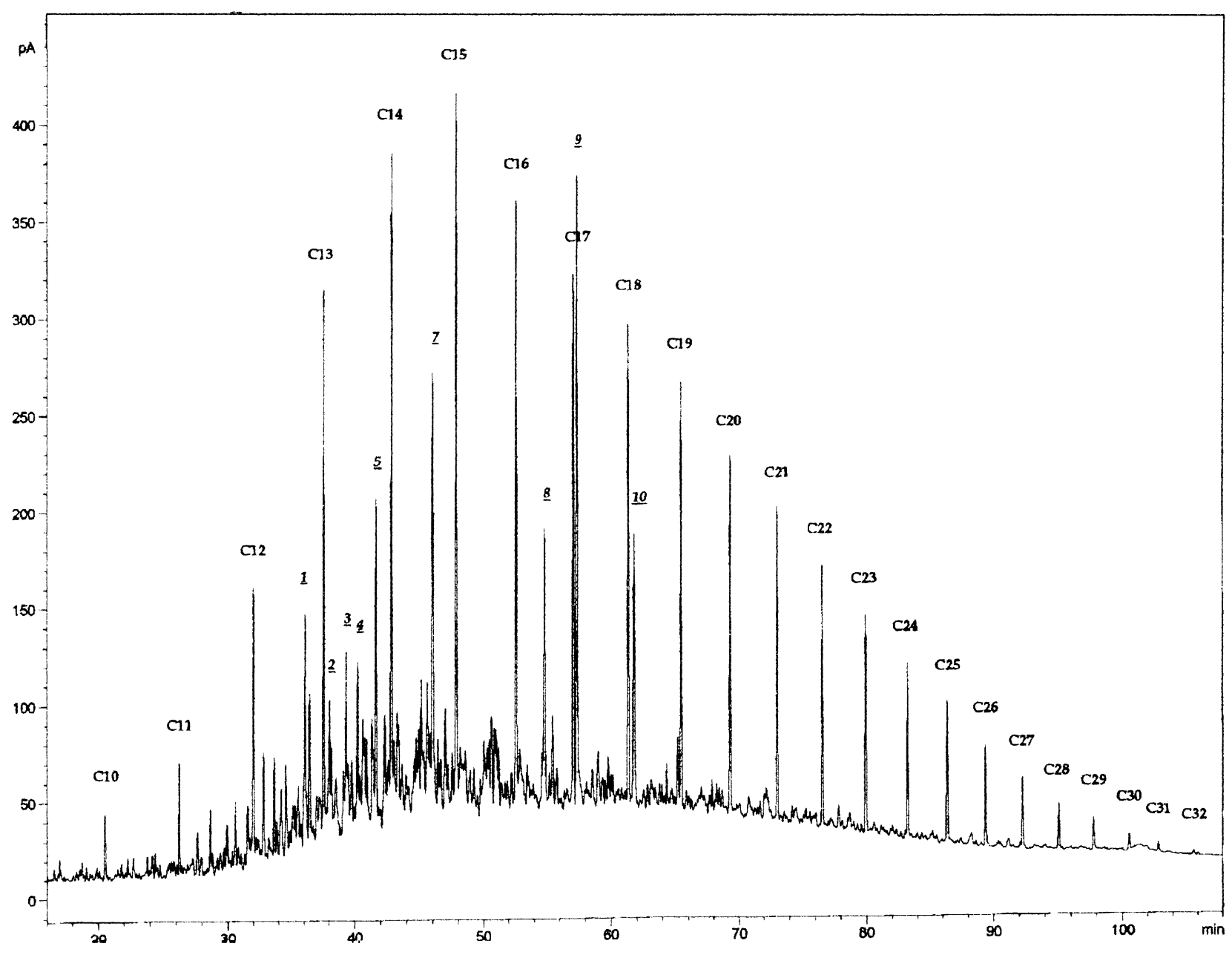

Fig. 1. Chromatographic analysis of diesel NS. The $n$-alkanes are identified by their chain length.

The size difference effects and free volume contributions, given by $\ln \gamma^{\text {comb-fv }}$, are described by the Flory-free volume equation [16]:

$$
\ln \gamma_{i}^{\text {comb-fv }}=\ln \frac{\phi_{i}}{x_{i}}+1-\frac{\phi_{i}}{x_{i}}
$$

with $\phi_{i}=\frac{x_{i}\left(V_{i}^{1 / 3}-V_{\mathrm{W} i}^{1 / 3}\right)^{3.3}}{\sum_{j} x_{j}\left(V_{j}^{1 / 3}-V_{\mathrm{W} j}^{1 / 3}\right)^{3.3}}$,

where $V_{i}$ is the molar volume and $V_{W i}$ is the van der Waals volume of component $i$.

\subsection{The solid phase non-ideality-Predictive UNIQUAC}

The solid phase non-ideality will be described by the Predictive UNIQUAC model $[5,6]$. This is a version of the original UNIQUAC where

$$
\begin{aligned}
\frac{g^{\mathrm{E}}}{\mathrm{R} T}= & \sum_{i=1}^{n} x_{i} \ln \left(\frac{\Phi_{i}}{x_{i}}\right)+\frac{Z}{2} \sum_{i=1}^{n} q_{i} x_{i} \ln \frac{\theta_{i}}{\Phi_{i}} \\
& -\sum_{i=1}^{n} x_{i} q_{i} \ln \left[\sum_{j=1}^{n} \theta_{j} \exp \left(-\frac{\lambda_{i j}-\lambda_{i i}}{q_{i} \mathrm{R} T}\right)\right]
\end{aligned}
$$

with

$$
\Phi_{i}=\frac{x_{i} r_{i}}{\sum_{j} x_{j} r_{j}} \text { and } \theta_{i}=\frac{x_{i} q_{i}}{\sum_{j} x_{j} q_{j}}
$$

using a new definition for the structural parameters $r$ and $q$ [6]. Correlations for these parameters are presented in Appendix A.

The predictive local composition concept [5] allows an estimation of the interaction energies, $\lambda_{i j}$, used by these models. The pair interaction energies between two identical molecules are estimated from the heat of sublimation of an 




Fig. 2. Diagram of the thermostatic equilibrium cell used.

orthorhombic crystal of the pure component,

$\lambda_{i i}=-\frac{2}{Z}\left(\Delta h_{\mathrm{sblm}_{i}}-\mathrm{R} T\right)$

Here $Z$ is the coordination number and has a value of $Z=6$ for orthorhombic crystals. The heats of sublimation, $h_{\text {sblm }}=$ $h_{\text {vap }}+h_{\mathrm{m}}+h_{\mathrm{tr}}$, are calculated at the melting temperature of the pure component. The heat of vaporisation $h_{\text {vap }}$ is assessed using a correlation by Morgan and Kobayashi [17].

The pair interaction energy between two non-identical molecules is given by

$\lambda_{i j}=\lambda_{j j}$

where $j$ is the $n$-alkane with the shorter chain of the pair $i j$.

The solid-liquid equilibrium model is thus a purely predictive model that uses in the calculation of the phase behaviour nothing but pure component properties.

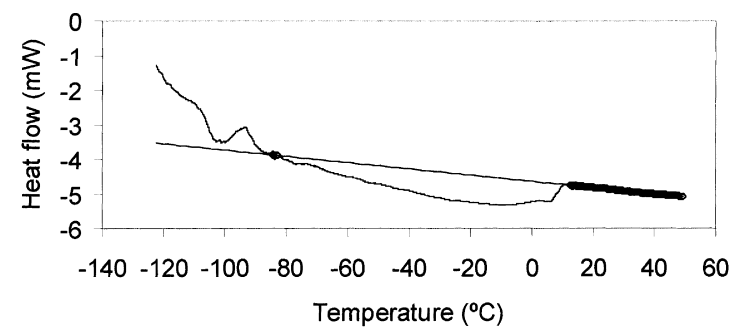

Fig. 3. DSC curve for diesel NS with description of the baseline used. Region used to fit base line is in bold.
Table 2

Diesel S: liquid phase experimental composition (mass fractions)

\begin{tabular}{|c|c|c|c|c|}
\hline \multirow[t]{2}{*}{ Alkane } & \multicolumn{4}{|l|}{$T\left({ }^{\circ} \mathrm{C}\right)$} \\
\hline & -4.8 & -10.0 & -15.0 & -20.0 \\
\hline$n$-C10 & $1.58 \mathrm{E}-02$ & $1.69 \mathrm{E}-02$ & $1.89 \mathrm{E}-02$ & $1.87 \mathrm{E}-02$ \\
\hline$n-\mathrm{C} 11$ & $1.81 \mathrm{E}-02$ & $1.91 \mathrm{E}-02$ & $2.12 \mathrm{E}-02$ & $2.12 \mathrm{E}-02$ \\
\hline$n-\mathrm{C} 12$ & $4.76 \mathrm{E}-02$ & $5.13 \mathrm{E}-02$ & $5.65 E-02$ & $5.69 \mathrm{E}-02$ \\
\hline$n-\mathrm{C} 13$ & $9.23 \mathrm{E}-02$ & $9.83 \mathrm{E}-02$ & $1.08 \mathrm{E}-01$ & $1.09 \mathrm{E}-01$ \\
\hline$n-\mathrm{C} 14$ & $1.07 \mathrm{E}-01$ & $1.14 \mathrm{E}-01$ & $1.24 \mathrm{E}-01$ & $1.26 \mathrm{E}-01$ \\
\hline$n-\mathrm{C} 15$ & $1.28 \mathrm{E}-01$ & $1.37 \mathrm{E}-01$ & $1.49 \mathrm{E}-01$ & $1.50 \mathrm{E}-01$ \\
\hline$n-\mathrm{C} 16$ & $1.05 \mathrm{E}-01$ & $1.11 \mathrm{E}-01$ & $1.22 \mathrm{E}-01$ & $1.22 \mathrm{E}-01$ \\
\hline$n-\mathrm{C} 17$ & $1.01 \mathrm{E}-01$ & $1.07 \mathrm{E}-01$ & $1.16 \mathrm{E}-01$ & $1.14 \mathrm{E}-01$ \\
\hline$n-\mathrm{C} 18$ & $8.50 \mathrm{E}-02$ & $8.95 \mathrm{E}-02$ & $9.51 \mathrm{E}-02$ & $8.76 \mathrm{E}-02$ \\
\hline$n-\mathrm{C} 19$ & $7.37 \mathrm{E}-02$ & $7.64 \mathrm{E}-02$ & $7.39 E-02$ & $6.20 \mathrm{E}-02$ \\
\hline$n-\mathrm{C} 20$ & $6.49 \mathrm{E}-02$ & $6.36 \mathrm{E}-02$ & $5.12 \mathrm{E}-02$ & $4.07 \mathrm{E}-02$ \\
\hline$n-\mathrm{C} 21$ & $5.51 \mathrm{E}-02$ & $4.83 \mathrm{E}-02$ & $3.11 \mathrm{E}-02$ & $2.81 \mathrm{E}-02$ \\
\hline$n-\mathrm{C} 22$ & $3.91 \mathrm{E}-02$ & $2.86 \mathrm{E}-02$ & $1.33 \mathrm{E}-02$ & $1.69 \mathrm{E}-02$ \\
\hline$n-\mathrm{C} 23$ & $2.64 \mathrm{E}-02$ & $1.63 E-02$ & $6.65 E-03$ & $1.26 \mathrm{E}-02$ \\
\hline$n-\mathrm{C} 24$ & $1.62 \mathrm{E}-02$ & $8.82 \mathrm{E}-03$ & $3.75 E-03$ & $9.71 \mathrm{E}-03$ \\
\hline$n-\mathrm{C} 25$ & $1.15 \mathrm{E}-02$ & $7.37 \mathrm{E}-03$ & $4.90 \mathrm{E}-03$ & $9.96 \mathrm{E}-03$ \\
\hline$n-\mathrm{C} 26$ & $6.44 \mathrm{E}-03$ & $3.51 \mathrm{E}-03$ & $2.23 \mathrm{E}-03$ & $6.04 \mathrm{E}-03$ \\
\hline$n-\mathrm{C} 27$ & $3.11 \mathrm{E}-03$ & $1.40 \mathrm{E}-03$ & $5.29 \mathrm{E}-04$ & $3.33 \mathrm{E}-03$ \\
\hline$n-\mathrm{C} 28$ & $2.32 \mathrm{E}-03$ & $1.06 \mathrm{E}-03$ & $5.71 \mathrm{E}-04$ & $2.48 \mathrm{E}-03$ \\
\hline$n-\mathrm{C} 29$ & $9.64 \mathrm{E}-04$ & $7.64 \mathrm{E}-04$ & $3.28 \mathrm{E}-04$ & $1.18 \mathrm{E}-03$ \\
\hline$n-\mathrm{C} 30$ & $6.57 \mathrm{E}-04$ & $3.17 \mathrm{E}-04$ & $1.97 \mathrm{E}-04$ & $7.80 \mathrm{E}-04$ \\
\hline$n-\mathrm{C} 31$ & $3.74 \mathrm{E}-04$ & $0.00 \mathrm{E}+00$ & $0.00 \mathrm{E}+00$ & $0.00 \mathrm{E}+00$ \\
\hline
\end{tabular}

\section{Results}

A compositional analysis was done by GC for diesels $\mathrm{S}$ and NS and is presented in Table 1. It shows a slight increase in the concentration of a number of paraffins and in the global paraffin content of the mixture after desulphuration. The variation in the average molecular weight, although within the experimental uncertainty, points in the same direction.

An analysis by GC-MS shows more than 400 compounds

Table 3

Diesel S: solid phase experimental composition (mass fractions)

\begin{tabular}{lllll}
\hline Alkane & $T\left({ }^{\circ} \mathrm{C}\right)$ & & & \\
\cline { 2 - 5 } & -4.8 & -10.0 & -15.0 & -20.0 \\
\hline$n$-C18 & $2.22 \mathrm{E}-03$ & $6.38 \mathrm{E}-04$ & $1.47 \mathrm{E}-02$ & $4.26 \mathrm{E}-02$ \\
$n$-C19 & $8.53 \mathrm{E}-03$ & $1.17 \mathrm{E}-02$ & $4.35 \mathrm{E}-02$ & $8.38 \mathrm{E}-02$ \\
$n$-C20 & $1.99 \mathrm{E}-02$ & $3.61 \mathrm{E}-02$ & $9.11 \mathrm{E}-02$ & $1.38 \mathrm{E}-01$ \\
$n$-C21 & $5.68 \mathrm{E}-02$ & $8.77 \mathrm{E}-02$ & $1.33 \mathrm{E}-01$ & $1.39 \mathrm{E}-01$ \\
$n$-C22 & $1.17 \mathrm{E}-01$ & $1.31 \mathrm{E}-01$ & $1.49 \mathrm{E}-01$ & $1.31 \mathrm{E}-01$ \\
$n$-C23 & $1.71 \mathrm{E}-01$ & $1.49 \mathrm{E}-01$ & $1.41 \mathrm{E}-01$ & $1.18 \mathrm{E}-01$ \\
$n$-C24 & $1.78 \mathrm{E}-01$ & $1.46 \mathrm{E}-01$ & $1.19 \mathrm{E}-01$ & $9.52 \mathrm{E}-02$ \\
$n$-C25 & $1.55 \mathrm{E}-01$ & $1.33 \mathrm{E}-01$ & $9.58 \mathrm{E}-02$ & $7.69 \mathrm{E}-02$ \\
$n$-C26 & $1.06 \mathrm{E}-01$ & $9.78 \mathrm{E}-02$ & $7.20 \mathrm{E}-02$ & $5.79 \mathrm{E}-02$ \\
$n$-C27 & $6.90 \mathrm{E}-02$ & $7.54 \mathrm{E}-02$ & $5.36 \mathrm{E}-02$ & $4.34 \mathrm{E}-02$ \\
$n$-C28 & $4.22 \mathrm{E}-02$ & $5.14 \mathrm{E}-02$ & $3.48 \mathrm{E}-02$ & $2.78 \mathrm{E}-02$ \\
$n$-C29 & $3.86 \mathrm{E}-02$ & $3.58 \mathrm{E}-02$ & $2.47 \mathrm{E}-02$ & $2.18 \mathrm{E}-02$ \\
$n$-C30 & $1.69 \mathrm{E}-02$ & $2.31 \mathrm{E}-02$ & $1.28 \mathrm{E}-02$ & $1.06 \mathrm{E}-02$ \\
$n$-C31 & $9.85 \mathrm{E}-03$ & $1.44 \mathrm{E}-02$ & $8.08 \mathrm{E}-03$ & $8.37 \mathrm{E}-03$ \\
$n$-C32 & $9.46 \mathrm{E}-03$ & $6.05 \mathrm{E}-03$ & $3.77 \mathrm{E}-03$ & $3.94 \mathrm{E}-03$ \\
\hline
\end{tabular}


Table 4

Diesel S: percentage of total paraffins crystallised

\begin{tabular}{lllll}
\hline$T\left({ }^{\circ} \mathrm{C}\right)$ & -4.8 & -10.0 & -15.0 & -20.0 \\
Paraffins crystallised $(\%)$ & 3.18 & 15.22 & 24.78 & 21.67 \\
\hline
\end{tabular}

present in the diesel. Using the same temperature program and similar columns as in the GC it was possible to confirm that the peak superposition for the $n$-alkanes was negligible with the exception of $n$-C25 were it was not possible to completely separate the paraffin from another non-identified compound.

The study in the equilibrium cell aims at acquiring the composition of the phases in equilibrium and the fraction of solids in the mixture. Compositions of the liquid and residual phase, composed by solids and entrapped liquid, were analysed by GC. The procedure to assess the solid phase composition is described in Appendix A. The experimental phase behaviour data measured can be found in Tables 2-7.

A comparison between model predictions and the experimental data is presented for diesel NS in Figs. 4-7 and for diesel $\mathrm{S}$ in Figs. 8-11. The figures would be unreadable with all the $20 n$-alkanes and thus only some selected paraffins are presented. In the modelling, pseudo compounds are used to describe the aromatics and naphthenics. Hexylbenzene is used to represent the aromatics and a trimethyltridecane represents the branched alkanes. The composition in aromatics and naphthenics was defined by the PNA analysis. The choice of the pseudo compounds was done to match average molecular weight of the diesel. The use of other pseudo compounds would not have a significant effect on the final results as long as the average molecular weight of the diesel was respected.
Figs. 4 and 8 show the composition variation of the paraffins in the liquid phase with temperature. The mass fractions presented are related only to the paraffins. They do not take into account the solvent. The trends are similar in both diesels with the liquid getting richer in the lower paraffins and poorer in the heavier as the temperature decreases. Some intermediate paraffins, such as octadecane, that do not precipitate at the beginning or precipitate very little, and at low temperatures have their precipitation rate increased go through a maximum in composition. The model provides an excellent description of the data. The liquid phase composition for all the paraffins at a given temperature $\left(-4.8^{\circ} \mathrm{C}\right)$ is also presented in Figs. 5 and 9. This shows the composition distribution of the paraffins in the liquid phase and the performance of the model for all the paraffins. This is generally very good with the exception of $n$-C25 where, as discussed above, the experimental composition has an error due to peak superposition.

The temperature dependence of the global solid phase composition can be seen in Figs. 6 and 10. Although this is an ongoing discussion in this field, today there seems to be enough experimental evidence that in wax deposition a multiphase equilibrium takes place $[8,18,19]$. The solution of paraffins presents multiple solid phases with different compositions, however, the experimental apparatus used in this work can only provide a global solid phase composition. Although the model predicts the coexistence of as many as three different solid phases for this mixture, unlike previous works $[6,20]$ just the global solid phase composition is presented. Only the paraffins heavier than $n$-C18 (including this) were found in the solid within the temperature range studied. The first crystal is richer in heavier alkanes and as temperature decreases their fraction

Table 5

Diesel NS: liquid phase experimental composition (mass fractions)

\begin{tabular}{|c|c|c|c|c|c|c|}
\hline \multirow[t]{2}{*}{ Alkane } & \multicolumn{6}{|l|}{$T\left({ }^{\circ} \mathrm{C}\right)$} \\
\hline & -22.0 & -20.0 & -15.0 & -10.0 & -5.1 & -4.8 \\
\hline$n-\mathrm{C} 10$ & $1.92 \mathrm{E}-02$ & $1.58 \mathrm{E}-02$ & $1.70 \mathrm{E}-02$ & $1.58 \mathrm{E}-02$ & $1.47 \mathrm{E}-02$ & $1.54 \mathrm{E}-02$ \\
\hline$n-\mathrm{C} 11$ & $2.37 \mathrm{E}-02$ & $2.13 E-02$ & $2.16 \mathrm{E}-02$ & $2.01 \mathrm{E}-02$ & $1.88 \mathrm{E}-02$ & $1.91 \mathrm{E}-02$ \\
\hline$n-\mathrm{C} 12$ & $5.62 \mathrm{E}-02$ & $4.94 \mathrm{E}-02$ & $4.82 \mathrm{E}-02$ & $4.64 \mathrm{E}-02$ & $4.41 \mathrm{E}-02$ & $4.25 \mathrm{E}-02$ \\
\hline n-C13 & $1.22 \mathrm{E}-01$ & $1.17 \mathrm{E}-01$ & $1.10 \mathrm{E}-01$ & $1.01 \mathrm{E}-01$ & $9.53 E-02$ & $9.69 \mathrm{E}-02$ \\
\hline$n-\mathrm{C} 14$ & $1.40 \mathrm{E}-01$ & $1.35 \mathrm{E}-01$ & $1.26 \mathrm{E}-01$ & $1.17 \mathrm{E}-01$ & $1.10 \mathrm{E}-01$ & $1.11 \mathrm{E}-01$ \\
\hline$n-\mathrm{C} 15$ & $1.72 \mathrm{E}-01$ & $1.66 \mathrm{E}-01$ & $1.55 \mathrm{E}-01$ & $1.44 \mathrm{E}-01$ & $1.34 \mathrm{E}-01$ & $1.35 \mathrm{E}-01$ \\
\hline$n-\mathrm{C} 16$ & $1.33 \mathrm{E}-01$ & $1.30 \mathrm{E}-01$ & $1.21 \mathrm{E}-01$ & $1.14 \mathrm{E}-01$ & $1.07 \mathrm{E}-01$ & $1.06 \mathrm{E}-01$ \\
\hline$n-\mathrm{C} 17$ & $1.19 \mathrm{E}-01$ & $1.22 \mathrm{E}-01$ & $1.16 \mathrm{E}-01$ & $1.08 \mathrm{E}-01$ & $1.01 \mathrm{E}-01$ & $9.86 \mathrm{E}-02$ \\
\hline$n-\mathrm{C} 18$ & $8.16 \mathrm{E}-02$ & $8.98 \mathrm{E}-02$ & $9.36 \mathrm{E}-02$ & $9.12 \mathrm{E}-02$ & $8.56 \mathrm{E}-02$ & $8.50 \mathrm{E}-02$ \\
\hline$n-\mathrm{C} 19$ & $4.95 \mathrm{E}-02$ & $6.06 \mathrm{E}-02$ & $7.32 \mathrm{E}-02$ & $7.73 \mathrm{E}-02$ & $7.43 \mathrm{E}-02$ & $7.45 \mathrm{E}-02$ \\
\hline$n-\mathrm{C} 20$ & $3.11 \mathrm{E}-02$ & $3.87 \mathrm{E}-02$ & $5.36 \mathrm{E}-02$ & $6.55 \mathrm{E}-02$ & $6.78 \mathrm{E}-02$ & $6.75 \mathrm{E}-02$ \\
\hline$n-\mathrm{C} 21$ & $1.83 \mathrm{E}-02$ & $2.15 \mathrm{E}-02$ & $3.25 \mathrm{E}-02$ & $4.52 \mathrm{E}-02$ & $5.43 \mathrm{E}-02$ & $5.42 \mathrm{E}-02$ \\
\hline$n-\mathrm{C} 22$ & $1.05 \mathrm{E}-02$ & $1.06 \mathrm{E}-02$ & $1.38 \mathrm{E}-02$ & $2.49 \mathrm{E}-02$ & $3.78 \mathrm{E}-02$ & $3.79 \mathrm{E}-02$ \\
\hline$n-\mathrm{C} 23$ & $6.39 \mathrm{E}-03$ & $6.57 \mathrm{E}-03$ & $6.80 \mathrm{E}-03$ & $1.30 \mathrm{E}-02$ & $2.41 \mathrm{E}-02$ & $2.45 \mathrm{E}-02$ \\
\hline$n-\mathrm{C} 24$ & $4.78 \mathrm{E}-03$ & $4.60 \mathrm{E}-03$ & $3.60 \mathrm{E}-03$ & $6.23 \mathrm{E}-03$ & $1.35 \mathrm{E}-02$ & $1.37 \mathrm{E}-02$ \\
\hline$n-\mathrm{C} 25$ & $6.39 \mathrm{E}-03$ & $6.43 \mathrm{E}-03$ & $4.54 \mathrm{E}-03$ & $5.76 \mathrm{E}-03$ & $9.55 \mathrm{E}-03$ & $9.96 \mathrm{E}-03$ \\
\hline$n-\mathrm{C} 26$ & $3.03 \mathrm{E}-03$ & $2.84 \mathrm{E}-03$ & $1.82 \mathrm{E}-03$ & $2.77 \mathrm{E}-03$ & $4.91 \mathrm{E}-03$ & $4.98 \mathrm{E}-03$ \\
\hline$n-\mathrm{C} 27$ & $1.63 \mathrm{E}-03$ & $1.32 \mathrm{E}-03$ & $7.95 \mathrm{E}-04$ & $8.54 \mathrm{E}-04$ & $2.04 \mathrm{E}-03$ & $2.08 \mathrm{E}-03$ \\
\hline$n-\mathrm{C} 28$ & $1.51 \mathrm{E}-03$ & $1.10 \mathrm{E}-03$ & $4.71 E-04$ & $8.23 \mathrm{E}-04$ & $1.59 \mathrm{E}-03$ & $1.57 \mathrm{E}-03$ \\
\hline
\end{tabular}


Table 6

Diesel NS: solid phase experimental composition (mass fractions)

\begin{tabular}{|c|c|c|c|c|c|c|}
\hline \multirow[t]{2}{*}{ Alkane } & \multicolumn{6}{|l|}{$T\left({ }^{\circ} \mathrm{C}\right)$} \\
\hline & -4.8 & -5.1 & -10.0 & -15.0 & -20.0 & -22.8 \\
\hline$n-\mathrm{C} 18$ & $6.56 \mathrm{E}-02$ & $4.56 \mathrm{E}-02$ & $1.46 \mathrm{E}-02$ & - & $8.78 \mathrm{E}-03$ & $4.80 \mathrm{E}-03$ \\
\hline$n-\mathrm{C} 19$ & $1.08 \mathrm{E}-01$ & $8.73 E-02$ & $4.47 \mathrm{E}-02$ & $1.32 \mathrm{E}-02$ & $1.01 \mathrm{E}-02$ & $6.37 \mathrm{E}-03$ \\
\hline$n-\mathrm{C} 20$ & $1.35 \mathrm{E}-01$ & $1.23 \mathrm{E}-01$ & $9.04 \mathrm{E}-02$ & $4.42 \mathrm{E}-02$ & $2.62 \mathrm{E}-02$ & $2.00 \mathrm{E}-02$ \\
\hline$n-\mathrm{C} 21$ & $1.33 \mathrm{E}-01$ & $1.42 \mathrm{E}-01$ & $1.29 \mathrm{E}-01$ & $9.61 \mathrm{E}-02$ & $5.22 \mathrm{E}-02$ & $4.60 \mathrm{E}-02$ \\
\hline$n-\mathrm{C} 22$ & $1.19 \mathrm{E}-01$ & $1.35 \mathrm{E}-01$ & $1.48 \mathrm{E}-01$ & $1.42 \mathrm{E}-01$ & $1.01 \mathrm{E}-01$ & $9.09 \mathrm{E}-02$ \\
\hline$n-\mathrm{C} 23$ & $1.04 \mathrm{E}-01$ & $1.19 \mathrm{E}-01$ & $1.38 \mathrm{E}-01$ & $1.58 \mathrm{E}-01$ & $1.48 \mathrm{E}-01$ & $1.39 \mathrm{E}-01$ \\
\hline$n-\mathrm{C} 24$ & $8.42 \mathrm{E}-02$ & $9.72 \mathrm{E}-02$ & $1.20 \mathrm{E}-01$ & $1.51 \mathrm{E}-01$ & $1.59 \mathrm{E}-01$ & $1.59 \mathrm{E}-01$ \\
\hline$n-\mathrm{C} 25$ & $6.71 \mathrm{E}-02$ & $7.69 \mathrm{E}-02$ & $9.74 \mathrm{E}-02$ & $1.26 \mathrm{E}-01$ & $1.43 \mathrm{E}-01$ & $1.52 \mathrm{E}-01$ \\
\hline$n-\mathrm{C} 26$ & $5.13 \mathrm{E}-02$ & $5.86 \mathrm{E}-02$ & $7.24 \mathrm{E}-02$ & $9.56 \mathrm{E}-02$ & $1.24 \mathrm{E}-01$ & $1.24 \mathrm{E}-01$ \\
\hline$n-\mathrm{C} 27$ & $3.49 \mathrm{E}-02$ & $4.19 \mathrm{E}-02$ & $5.46 \mathrm{E}-02$ & $7.25 \mathrm{E}-02$ & $8.93 E-02$ & $9.78 \mathrm{E}-02$ \\
\hline$n-\mathrm{C} 28$ & $2.37 \mathrm{E}-02$ & $2.97 \mathrm{E}-02$ & $3.33 \mathrm{E}-02$ & $4.42 \mathrm{E}-02$ & $5.80 \mathrm{E}-02$ & $6.35 \mathrm{E}-02$ \\
\hline$n-\mathrm{C} 29$ & $1.74 \mathrm{E}-02$ & $2.01 E-02$ & $2.43 \mathrm{E}-02$ & $3.06 \mathrm{E}-02$ & $3.97 \mathrm{E}-02$ & $4.67 \mathrm{E}-02$ \\
\hline$n-\mathrm{C} 30$ & $9.69 \mathrm{E}-03$ & $1.15 \mathrm{E}-02$ & $1.34 \mathrm{E}-02$ & $1.61 \mathrm{E}-02$ & $2.16 \mathrm{E}-02$ & $2.38 \mathrm{E}-02$ \\
\hline n-C31 & $5.89 \mathrm{E}-03$ & $6.13 \mathrm{E}-03$ & $7.79 \mathrm{E}-03$ & $1.05 \mathrm{E}-02$ & $1.36 \mathrm{E}-02$ & $1.58 \mathrm{E}-02$ \\
\hline$n-\mathrm{C} 32$ & $3.10 \mathrm{E}-03$ & $3.50 \mathrm{E}-03$ & $3.79 \mathrm{E}-03$ & - & $5.99 \mathrm{E}-03$ & $7.97 \mathrm{E}-03$ \\
\hline
\end{tabular}

Table 7

Diesel S: percentage of total paraffins crystallised

\begin{tabular}{lccccc}
\hline$T\left({ }^{\circ} \mathrm{C}\right)$ & -4.8 & -5.1 & -10.0 & -15.0 & -20.0 \\
Paraffins crystallised $(\%)$ & 6.84 & 10.58 & 12.22 & 21.72 & 31.21 \\
\hline
\end{tabular}

decreases as the solid phase becomes richer in light compounds such as $n$-C20. As for the liquid phase some intermediate compounds such as $n$-C23 go through a maximum. The global performance of the model is remarkable although it somewhat underestimates the composition of these intermediate compounds. One should, however, bear in mind that these are model predictions and nothing is fitted to the actual experimental data.

The fraction of solids in the partly crystallised solution was obtained both from the equilibrium cell and DSC measurements. It is not possible to claim a perfect fit between the two experimental measurements but given the uncertainty in the DSC baseline the agreement was found satisfactory. The model seems to follow closely the data obtained in the equilibrium cell. The deviations of this data at the lowest temperature are due to too short an equilibration time. Below $-20^{\circ} \mathrm{C}$ the $18 \mathrm{~h}$ used to equilibrate the cell do not seem enough.

The wax appearance temperature (WAT) was also measured by DSC. Runs at different heating rates were done and the value extrapolated to zero heating rate. The

Table 8

Experimental and model predictions for the wax appearance temperatures (WAT)

\begin{tabular}{lll}
\hline & WAT $\left({ }^{\circ} \mathrm{C}\right)$ & \\
\cline { 2 - 3 } & Experimental & Model \\
\hline Diesel S & $4.3 \pm 0.2$ & 4.9 \\
Diesel NS & $5.5 \pm 0.2$ & 5.4 \\
\hline
\end{tabular}

WATs found are presented in Table 8 and compared with the model predictions. The results support the previous indications that the desulphuration makes the diesel slightly heavier.

\section{Conclusions}

The differences between the diesels are, for most measurements, within the limits of experimental uncertainty. A direct comparison between them is thus not possible. Nevertheless the composition and wax appearance temperature measurements indicate that after the desulphuration the diesel becomes slightly heavier and thus somewhat less performing at low temperatures.

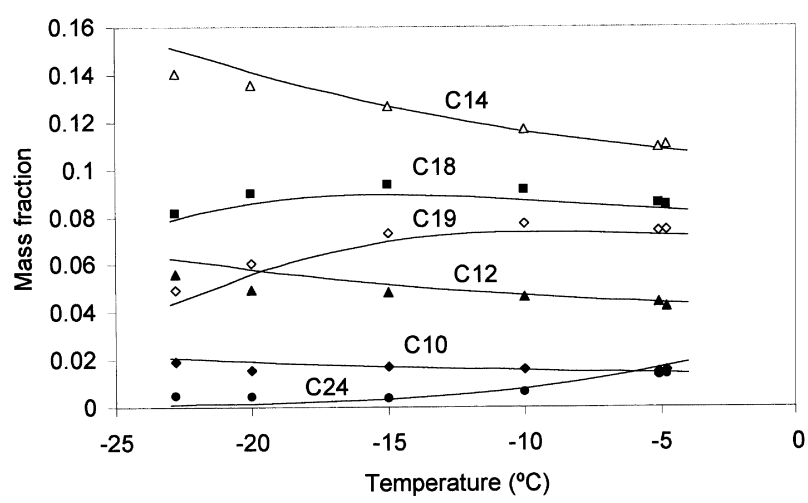

Fig. 4. Experimental and model predictions for the temperature dependence of the paraffins composition in the liquid phase for diesel NS. 




Fig. 5. Experimental and model predictions for the composition in paraffins in the liquid phase at $-4.8^{\circ} \mathrm{C}$ for diesel NS.

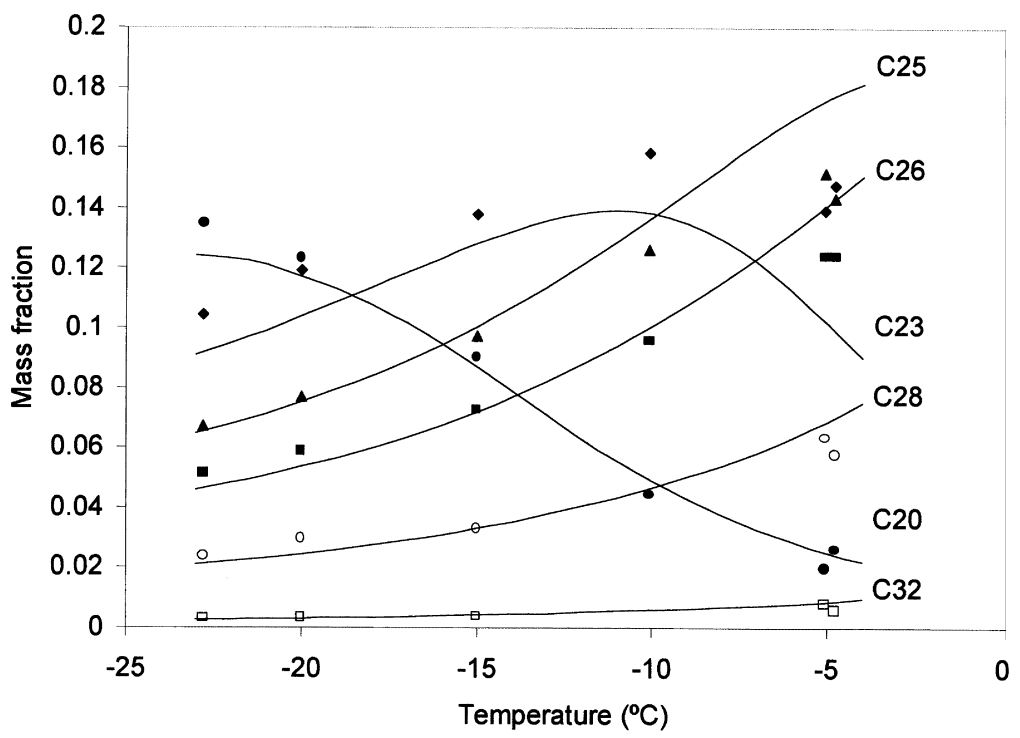

Fig. 6. Experimental and model predictions for the temperature dependence of the paraffins composition in the solid phase for diesel NS.

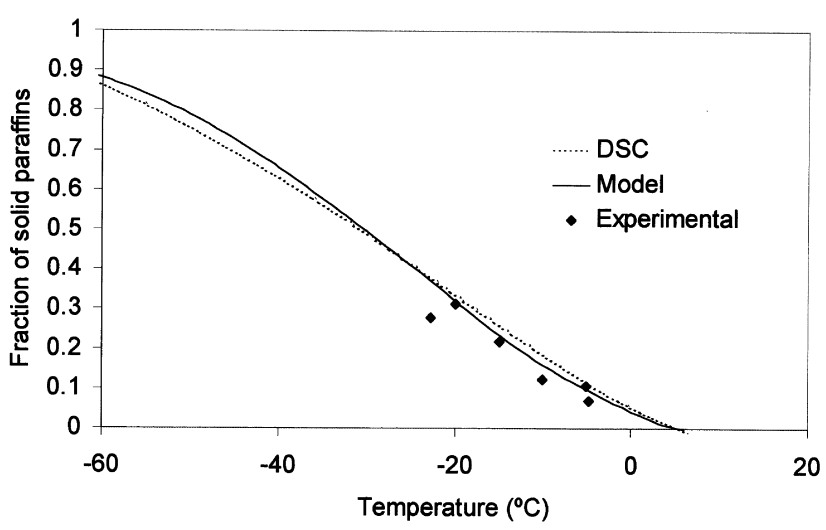

Fig. 7. Experimental (equilibrium cell and DSC) and model predictions for the fraction of crystallised paraffins in diesel NS.

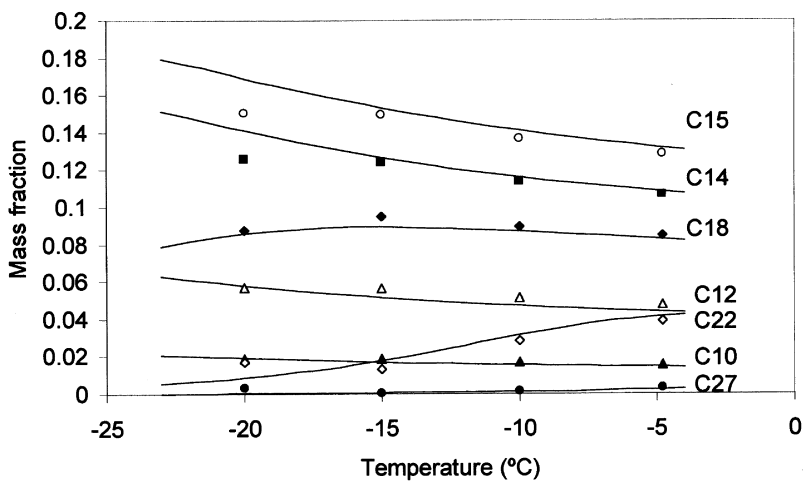

Fig. 8. Experimental and model predictions for the temperature dependence of the paraffins composition in the liquid phase for diesel S. 


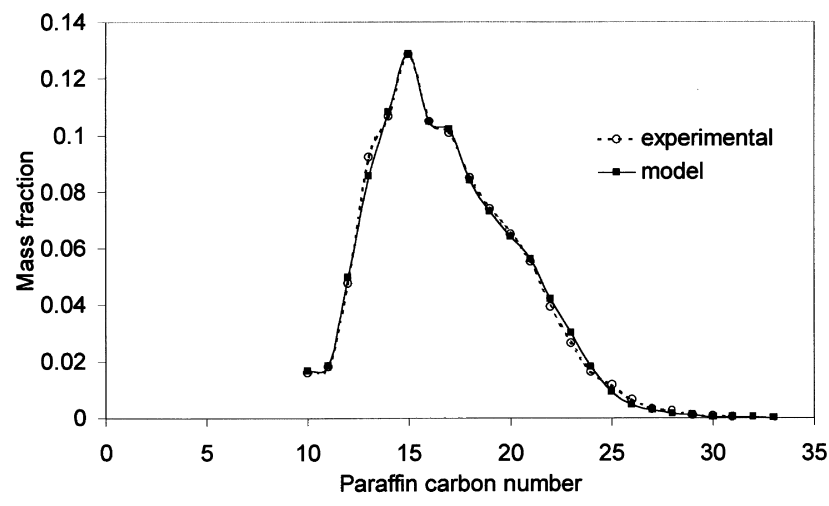

Fig. 9. Experimental and model predictions for the composition in paraffins in the liquid phase at $-4.8^{\circ} \mathrm{C}$ for diesel $\mathrm{S}$.
The thermodynamical model used to describe the phase behaviour of the diesels, based on the Predictive UNIQUAC model for the solid phase, provides an excellent description of the diesels' low temperature behaviour.

\section{Acknowledgements}

The authors would like to thank PETROGAL for the diesel samples and François Montel at ELF-Aquitaine for some composition measurements on the diesels. This work was partly founded by Fundação para a Ciěncia e Tecnologia, Portugal, under the project Praxis/P/EQU/12010/1998.

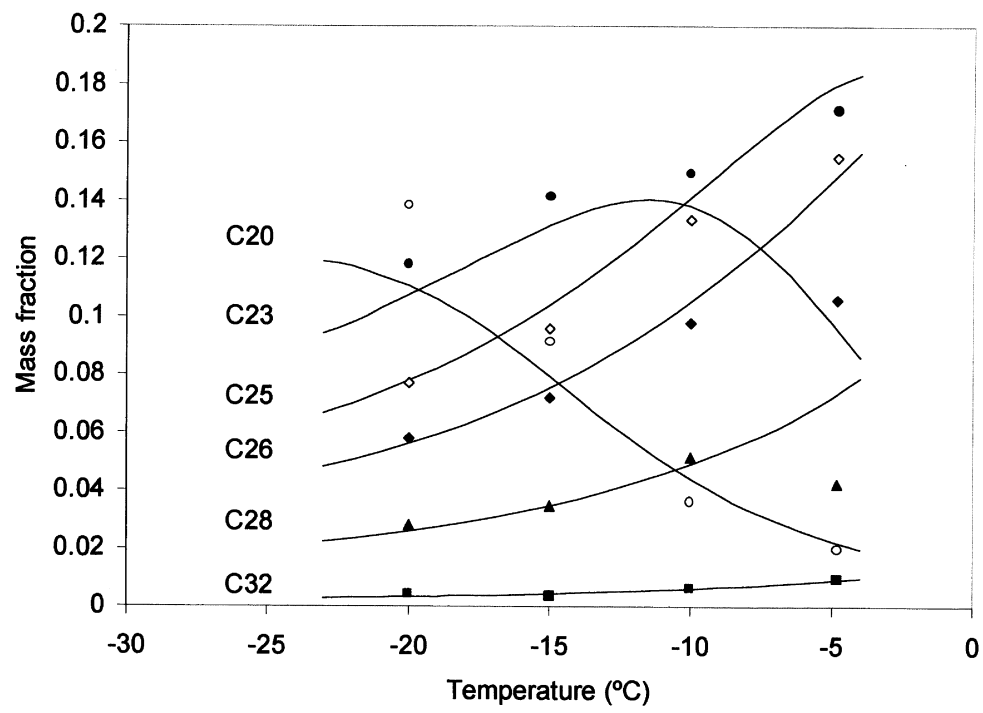

Fig. 10. Experimental and model predictions for the temperature dependence of the paraffins composition in the solid phase for diesel S.

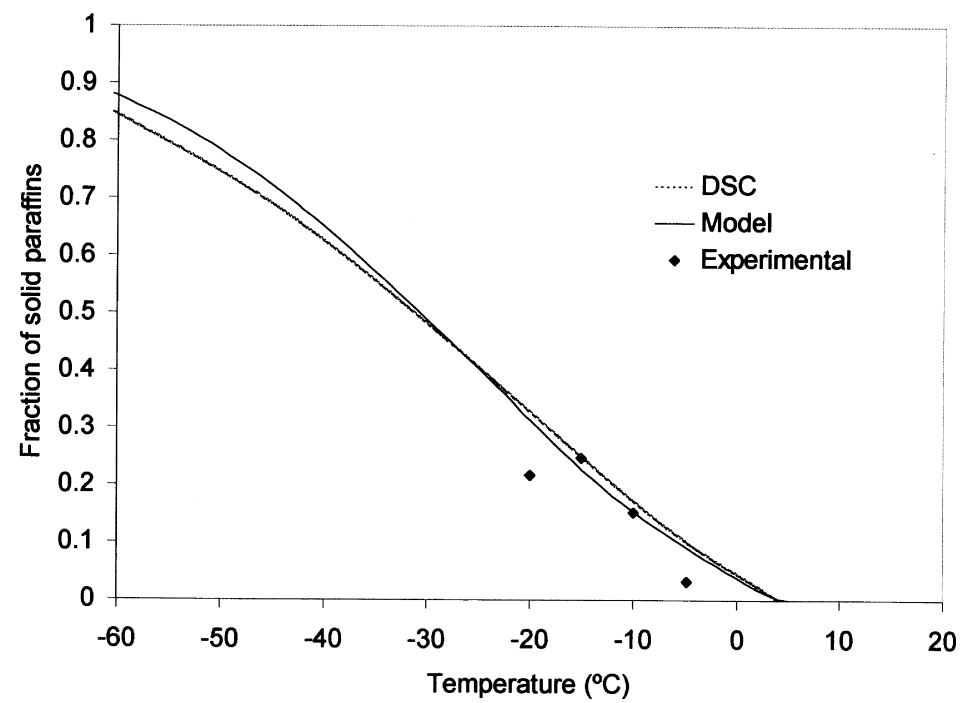

Fig. 11. Experimental (equilibrium cell and DSC) and model predictions for the fraction of crystallised paraffins in diesel S. 


\section{Appendix A}

\section{A.1. Calculation of solid phase compositions}

In the equilibrium cell there is a liquid, $\mathrm{L}$, a solid, $\mathrm{S}$, some entrapped liquid with the same composition as the liquid, EL, and a residual fraction made of solid and entrapped liquid, $\mathrm{R}(=\mathrm{S}+\mathrm{EL})$. There are also two sorts of compounds, those which crystallise, $i$, and those which do not, $k$. Since the composition of $\mathrm{L}$ and EL are the same,

$m_{k, i}^{\mathrm{L}}=w_{k, i}^{\mathrm{L}} m^{\mathrm{L}}$

and

$m_{k, i}^{\mathrm{EL}}=w_{k, i}^{\mathrm{L}} m^{\mathrm{EL}}$.

A parameter $Y$ is defined as:

$Y=\frac{m^{\mathrm{EL}}}{m^{\mathrm{L}}}=\frac{m_{k, i}^{\mathrm{EL}}}{m_{k, i}^{\mathrm{L}}}=\frac{m_{k}^{\mathrm{R}}}{m_{k}^{\mathrm{L}}}$

the last equality being valid because the $k$ components are not present in the solid phase. It allows the estimation of the $Y$ parameter for a mixture. Values of $Y$ are calculated for the $n$-alkanes between $\mathrm{C} 10$ and C20. The lightest crystallisable paraffin is identified as the first paraffin whose $Y$ parameter departs from the average value for the low paraffins. Using this average $Y$ value the estimation of the solid phase compositions is straightforward. Since

$m_{i}^{\mathrm{S}}=m_{i}^{\mathrm{R}}-Y m_{i}^{\mathrm{L}}$

the fraction of solid paraffins, $\alpha_{\mathrm{p}}$, is simply

$\alpha_{\mathrm{p}}=\frac{\sum m_{i}^{\mathrm{S}}}{\sum m_{\mathrm{p}}^{\mathrm{R}}+\sum m_{\mathrm{p}}^{\mathrm{L}}}$

where $\mathrm{p}$ stands for paraffins. Using a reference compound, the GC analysis allows quantification of all masses of paraffins in the liquid and residual fractions. From Eqs. (A4) and (A5) all compositions of the liquid phase and fractions of solids can be assessed from the measured values.

\section{A.2. Structural parameters}

Correlations for the $r$ and $q$ values used in the Predictive UNIQUAC are here presented. For an $n$-alkane with $n$ carbon atoms

$r_{n}=0.0148 * \mathrm{C}_{n}+0.00996$

$q_{n}=0.0185 * \mathrm{C}_{n}+0.0211$.

\section{A.3. Thermophysical properties}

The solid phases for both odd and even $n$-alkanes are postulated to be orthorhombic phases that undergo a solid-solid transition to a rotator phase before melting $[5,19]$. The temperatures of phase transition used are obtained from a correlation of the values of Broadhurst [13]:

$$
\begin{aligned}
T_{\mathrm{m}}[\mathrm{K}]= & 0.040 \mathrm{C}_{n}^{3}-2.2133 \mathrm{C}_{n}^{2}+46.197 \mathrm{C}_{n}-45.777 \\
\text { for } \mathrm{C}_{n}< & \mathrm{C}_{16} \\
T_{\mathrm{m}}[\mathrm{K}]= & 0.0028 \mathrm{C}_{n}^{3}-0.3185 \mathrm{C}_{n}^{2}+13.559 \mathrm{C}_{n} \\
& +143.15
\end{aligned}
$$

for $\mathrm{C}_{n} \geq \mathrm{C}_{16}$

$$
\begin{aligned}
T_{\text {tr }}[\mathrm{K}]= & -0.0038 \mathrm{C}_{n}^{3}-0.1159 \mathrm{C}_{n}^{2}+13.386 \mathrm{C}_{n} \\
& +108.79
\end{aligned}
$$

for $\mathrm{C}_{n}<\mathrm{C}_{16}$

$$
\begin{aligned}
T_{\text {tr }}[\mathrm{K}]= & 0.0038 \mathrm{C}_{n}^{3}-0.4126 \mathrm{C}_{n}^{2}+16.741 \mathrm{C}_{n} \\
& +99.885
\end{aligned}
$$

for $\mathrm{C}_{n} \geq \mathrm{C}_{16}$.

The heats of sublimation are considered to be temperature independent and calculated at the temperature of melting of the normal alkane. They are obtained adding the heats of vaporisation, melting and solid-solid transition. The heats of melting and solid phase transition used are the following correlations from the Broadhurst [13] values:

$$
\begin{aligned}
\Delta h_{\text {sblm }}=h_{\text {vap }}+ & h_{\mathrm{m}}+h_{\text {tr }} \\
\Delta h_{\mathrm{m}}[\mathrm{kJ} / \mathrm{mol}]= & -0.0009 \mathrm{C}_{n}^{3}-0.0011 \mathrm{C}_{n}^{2} \\
& +3.6119 \mathrm{C}_{n}-16.282
\end{aligned}
$$

for $\mathrm{C}_{n}<\mathrm{C}_{19}$

$$
\begin{aligned}
\Delta h_{\mathrm{m}}[\mathrm{kJ} / \mathrm{mol}]= & 0.0036 \mathrm{C}_{n}^{3}-0.2376 \mathrm{C}_{n}^{2} \\
& +7.400 \mathrm{C}_{n}-34.814
\end{aligned}
$$

for $\mathrm{C}_{n} \geq \mathrm{C}_{19}$

$$
\begin{aligned}
\Delta h_{\mathrm{tr}}[\mathrm{kJ} / \mathrm{mol}]= & 0.0009 \mathrm{C}_{n}^{3}+0.0011 \mathrm{C}_{n}^{2} \\
& +0.1668 \mathrm{C}_{n}+3.693
\end{aligned}
$$

for $\mathrm{C}_{n}<\mathrm{C}_{19}$

$$
\begin{aligned}
\Delta h_{\mathrm{tr}}[\mathrm{kJ} / \mathrm{mol}]= & -0.0032 \mathrm{C}_{n}^{3}+0.2353 \mathrm{C}_{n}^{2} \\
& -3.912 \mathrm{C}_{n}+25.261
\end{aligned}
$$

for $\mathrm{C}_{n} \geq \mathrm{C}_{19}$. 
The heats of vaporisation are estimated using the Morgan and Kobayashi model PERT2 [17].

\section{References}

[1] Auto-Oil Programme, Doc: COM(96)248, European Commission, Brussels, 1996.

[2] Neale T. Euro Sinergy Conference, Brussels, October 1997.

[3] Soares Mota J. CHEMPOR'98, Lisbon, September 1998.

[4] Wang SL, Flamberg A, Kikabhai T. Hydrocarb Process 1999;February:59.

[5] Coutinho JAP, Stenby EH. Ind Engng Chem Res 1996;35:918.

[6] Coutinho JAP. Ind Engng Chem Res 1998;37:4870.

[7] Pauly J, Dauphin C, Daridon JL. Fluid Phase Equilibria 1998;149:173.

[8] Dauphin C, Daridon JL, Coutinho JAP, Baylère P, Potin-Gautier M. Fluid Phase Equilibria 1999;161:135.

[9] Létoffé JM, Claudy P, Garcin M, Volle JL. Fuel 1995;74:92.

[10] Bosselet F, Létoffé JM, Claudy P, Valentin P. Thermochim Acta 1983;70:19.
[11] Coutinho JAP, Calange S, Ruffier-Meray V. Can J Chem Engng 1997;75:1075.

[12] Prausnitz JM, Lichtenthaler RN, Azevedo EG. Molecular thermodynamics of fluid-phase equilibria, 2. Englewood Cliffs, NJ: PrenticeHall, 1986.

[13] Broadhurst MG. J Res Natl Bur Standards 1962;66A:241.

[14] Fredenslund Aa, Gmehling J, Rasmussen P. Vapor-liquid equilibria using UNIFAC: a group-contribution method, Amsterdam: Elsevier Scientific, 1977.

[15] Larsen BL, Rasmussen P, Fredenslund Aa. Ind Engng Chem Res 1987;26:2274.

[16] Coutinho JAP, Andersen SI, Stenby EH. Fluid Phase Equilibria 1995;103:23

[17] Morgan DL, Kobayashi R. Fluid Phase Equilibria 1994;94:51.

[18] Coutinho JAP, Ruffier-Meray V. Ind Engng Chem Res 1997;36:4977.

[19] Gerson AR, Roberts KJ, Sherwood JN. Particle design via crystallisation. In: Ramanarayanan R, Kern W, Larson M, Sikdar S, editors. Am Inst Chem Engng Symp Ser, 284, 1991. p. 138.

[20] Coutinho JAP. Fluid Phase Equilibria 1999;158-160:447. 